\title{
Photoreactivity of riverine and phytoplanktonic dissolved organic matter and its effects on the dynamics of a bacterial community from the coastal Mediterranean Sea
}

\author{
Marine Blanchet, Camila Fernandez, Fabien Joux* \\ Sorbonne Universités, UPMC Univ Paris 06, CNRS, Laboratoire d'Océanographie \\ Microbienne (LOMIC), Observatoire Océanologique, F-66650, Banyuls/mer, France \\ * corresponding author: joux@obs-banyuls.fr
}

For submission to Progress in Oceanography Special issue MERMEX as full length research paper

\begin{abstract}
High solar radiation levels measured in the Mediterranean basin can result in photo-oxidation of dissolved organic matter (DOM) at the sea surface. The objective of the present study was to determine the effects of solar radiation on two contrasting sources of DOM (diatomderived DOM and riverine DOM) and to evaluate its effect on the growth and the composition of a bacterial community from the Mediterranean Sea. DOM was sequentially exposed to artificial solar radiation or kept in the dark and then added to microcosms containing coastal seawater. For both sources of DOM, light exposure induced photo-alterations by decreasing absorbance and fluorescence of colored dissolved organic matter. However, resulting effects on bacteria were contrasted. Photo-alteration of phytoplankton-derived DOM resulted in a lower bacterial growth during the three first days, without modifying the total dissolved organic carbon consumption. Moreover, after 3 days of incubation, the bacterial diversity as determined by $16 \mathrm{~S}$ rRNA gene pyrosequencing, revealed that DOM phototransformation led to a higher relative abundance of Alphaproteobacteria and a lower relative abundance of
\end{abstract} Gammaproteobacteria. A limited number of operational taxonomic units (OTUs) $(\mathrm{n}=44)$ 
explained $80 \%$ of the diversity changes between dark and the light treatments, with an equal number of positively and negatively affected OTUs. In contrast, the photobleaching measured on riverine DOM after sunlight exposure had no effect on both bacterial carbon cycling and composition during a 7-days biodegradation experiment. Our results demonstrate that the effects of solar radiation on DOM greatly differ according to the initial composition of DOM and that changes in bacterial composition, when occurred, showed diverse responses inside a same class of bacteria, underlying the necessity to use a sufficiently resolutive approach to describe them. A better understanding of the interactive effects of the biological degradation and the photoinduced degradation of DOM are required in the context of the global change affecting Mediterranean Sea.

Keywords: Dissolved organic matter, photo-oxidation, bacterial diversity, 16S rRNA pyrosequencing, Mediterranean Sea

\section{Introduction}

The composition of dissolved organic matter (DOM) in the marine environment is complex and the list of the dissolved compounds that can be characterized (e.g., simple sugars, amino acids, lipids, vitamins) represent only a small fraction of its total composition (Repeta 2015). Coastal waters are characterized by a high diversity of dissolved compounds due to the mixing of DOM of different origins that can be drained by the rivers or produced in situ by the marine organisms. The heterotrophic bacteria constitute the main actors in the degradation of DOM, using organic carbon for catabolism to obtain energy (bacterial respiration) or for anabolism to build new bacterial biomass (bacterial production) (Cotner and Biddanda 2002). The huge diversity of organic molecules available in the oceans is reflected by a large diversity of heterotrophic bacteria with different metabolic capabilities able to degrade them. Different studies have demonstrated the structuring effect of DOM on the bacterial community composition suggesting that specialists and generalists coexist in the environment (Kirchman et al. 2004 ; Landa et al. 2013 ; Blanchet et al. 2015). For instance, the degradation of humic substances that constitute large proportions of the recalcitrant riverine DOM, has been reported to be associated to Alphaproteobacteria, Gammaproteobacteria and Actinobacteria in coastal waters (Rocker et al. 2012), whereas the Flavobacteria (Baceteroidetes phylum) and the Roseobacter (Rhodobacteraceae family belonging to the 
Alphaproteobacteria class) were identified as important actors in the degradation of labile DOM produced during the phytoplankton blooms (Buchan et al. 2014).

Biogeochemical cycling of DOM in the oceans can be also influenced by abiotic processes through direct and indirect photochemical tranformations (Mopper et al. 2015). Photoreactions can induce partial or complete remineralization of DOM and also alter the bioavailability of DOM by modifying its chemical structure. The net effect of photoreaction on bioavailability of DOM can be either positive or negative depending on the initial characteristics of the DOM. For instance, photodegradation of riverine DOM, characterized by a high content of refractory humic substances, generally results in direct photomineralization or bacterial mineralization of photoproduced labile DOM and contributes to its fate in coastal waters (reviewed in Mopper et al. 2015). In contrast, photoreactions on DOM initially bioavailable, such as phytoplankton exudates, can induce the production of less bioavailable organic compounds (Benner and Biddanda 1998 ; Tranvik and Kokalj 1998 ; Bertilsson and Tranvik 2000). Negative effects can be explained by abiotic cross-linking, humification and polymerization of labile molecules, the production of reactive oxygen species or the release of toxic metals that can inhibit the bacterial activity (Glaeser et al. 2010 ; Mopper et al. 2015).

Beside the effects of the oxidation/degradation of DOM on bacterial metabolism, studies have focused on the changes in bacterial community composition and structure in aquatic ecosystems. By using DNA and RNA fingerprinting (Judd et al. 2007 ; Abboudi et al. 2008 ; Lønborg et al. 2016) or CARD-FISH techniques (Pérez and Sommaruga 2007 ; Piccini et al. 2009 ; Lønborg et al. 2013), these studies have revealed that some groups of bacteria can be favored when they are supplied with phototransformed DOM. Because bacterial community composition is increasingly viewed as a factor that contributes to controlling ecosystem functioning (Comte and del Giorgio 2011), precise identification of bacteria responsive to photochemical DOM transformations is a pivotal step to understand the global impact of solar radiation on biogeochemical processes in the oceans. Today, the use of high-throughput technologies for sequencing $16 \mathrm{~S}$ rRNA genes offers the opportunity to explore deeper and more thoroughly the microbial community composition (Zingler et al. 2012) in order to determine which bacterial species are responsive to DOM photoproducts or toxic photoproducts.

The Mediterranean Sea is a semi-enclosed sea surrounded by continents and is characterized by very short ventilation and residence times ( 70 years) when compared to the other oceans 
(200-1000 years). Because of its weak cloud coverage, the Mediterranean Sea is also subject to stronger solar radiation compared to oceanic areas of similar latitude (Mermex group 2011; Sempéré et al. 2015). This intense solar radiation may cause strong photochemical reactions in the photic layer especially in coastal area where chromophoric dissolved organic matter $(\mathrm{CDOM})$ is present in higher concentration (Sempéré et al. 2015). The Mediterranean Sea is also characterized by freshwater inputs, mostly discharged by northern rivers, that play a important role by enhancing primary productivity at large scales (Mermex group 2011). The plume of the Rhone River, the main river flowing into the western basin of the Mediterranean Sea, is associated with high values of primary production and organic carbon concentrations that can extend over a large area (Diaz et al. 2008). Solar radiation can play an important role in the biogeochemistry of this low-salinity and high productive surface water by affecting microbial components and by inducing photochemical reactions (Joux et al. 2009).

The objective of this study was to investigate the effects of solar radiation on two contrasting DOM sources and its subsequent impact on the activity and the composition of a coastal bacterial community in the Mediterranean Sea. For this purpose, we exposed DOM from the Rhone River and diatom-derived DOM (an important phytoplankton group present in the river plume [Wawick and Paul 2004]) to artificial sunlight and then added separately the same quantity of photo-oxidized DOM of each origin to a bacterial community to follow changes in dissolved organic carbon (DOC) assimilation, bacterial growth, production and diversity using tag pyrosequencing of $16 \mathrm{~S}$ rRNA genes. These changes were compared to those observed after the addition of unexposed DOM from the same sources.

\section{Materials and Methods}

\section{Preparation and irradiation of DOM}

Rhône river water (10L) was collected on $5^{\text {th }}$ June 2012 at the observatory station of the Rhône river in Arles (SORA) which is located near the Compagnie Nationale du Rhône gauging station using automatic samplers installed at the station. The flow rate was 2,190 $\mathrm{m}^{3} \cdot \mathrm{s}^{-1}$. River samples were filtered through $1.0 \mu \mathrm{m}$ pore size filter capsules to remove large particles and then through $0.2-\mu \mathrm{m}$ pore-size filter capsules (Polycap TC, Whatman) previously rinsed with $10 \% \mathrm{HCl}$ and washed with Milli-Q water. The algal extract was obtained from a non-axenic monoculture of Chaetoceros sp. (Bacillariophyceae) grown in 1-L Guillard's F/2. We modified the medium by removing the EDTA that contributed to $117 \mu \mathrm{M}$ 
DOC. The only sources of DOC in our medium were the vitamins (thiamin, biotin, cyanocobalamin) that represented less than $4 \mu \mathrm{M}$ DOC. The culture medium was sterilized by filtration $(0.2 \mu \mathrm{m})$ rather than autoclave to avoid potential DOC contamination. The culture was grown at $18^{\circ} \mathrm{C}$ under continuous light until the stationary phase ( $~ 8$ days). The culture was then sonicated in $40 \mathrm{ml}$ subfractions and then filtered sequentially through $1-\mu \mathrm{m}$ filter capsule and 0.2- $\mu \mathrm{m}$ and capsules filter (Polycap TC Whatman) previously rinsed with 10\% $\mathrm{HCl}$ and washed with Milli-Q water, in order to recover phytoplankton DOM and exudates.

Each type of filtered sample (Rhone River or phytoplankton extract) was then distributed into two $4 \mathrm{~L}$ quartz bottles previously precombusted $\left(450^{\circ} \mathrm{C}, 6 \mathrm{~h}\right)$. One bottle was maintained in the dark and the other one was exposed during $24 \mathrm{~h}$ under a solar simulator Suntest CPS+ (Atlas, $\mathrm{GmbH}$ ) equipped with a 1-kW xenon lamp, giving an optical output irradiance of 328 $\mathrm{W} \mathrm{m}{ }^{-2}$ PAR (400-700 nm), $43 \mathrm{~W} \mathrm{~m}^{-2}$ UV-A (315-400 nm) and $2.05 \mathrm{~W} \mathrm{~m}^{-2}$ UV-B (280-315 $\mathrm{nm}$ ) as measured with a UV/visible spectroradiometer RAMSES (Trios, Germany). This exposure corresponds to a natural dose received during two days in summer at the sea surface in the northwestern Mediterranean region (Abboudi et al. 2008). During irradiation, the quartz bottles were maintained at $15^{\circ} \mathrm{C}$ by submersion in a water bath connected to a cryothermostat. Subsamples were collected before and after sunlight exposure for dissolved organic carbon (DOC), dissolved organic nitrogen (DON), dissolved organic phosphorus (DOP), chromophoric dissolved organic matter (CDOM), fluorescent dissolved organic matter (FDOM) and inorganic nutrients analyses.

\section{Biodegradation experiment}

Two separate experiments were performed in June 2012 (Rhone River DOM experiment) and July 2012 (phytoplankton DOM experiment). After DOM irradiation of each experiment, surface water samples were collected from a coastal station in the NW Mediterranean Sea (SOLA station, Bay of Banyuls-sur-mer, France [ $\left.42^{\circ} 29^{\prime} \mathrm{N}, 3^{\circ} 08^{\prime} \mathrm{E}\right]$ ). Samples were filtered by gravity on $25-\mu \mathrm{m}$ mesh (Nytex) to remove large zooplankton and phytoplankton. For each experiment, nine precombusted $\left(450^{\circ} \mathrm{C}, 6 \mathrm{~h}\right)$ 4-L glass flasks were filled with 3-L filtered seawater and amended with DOM from either irradiated or dark treatments. For the phytoplankton experiment, three microcosms received $140-\mathrm{mL}$ (3.5\% final volume) of irradiated phytoplankton DOM and three others received $140-\mathrm{mL}$ of non-irradiated DOM. The last three microcosms did not receive any addition (control microcosms). For the Rhone experiment, three microcosms received $800-\mathrm{mL}$ (20\% final volume) of irradiated DOM coming from the Rhone and three microcosms were amended with $800-\mathrm{mL}$ of Rhone DOM 
maintained in the dark. The last three microcosms (control treatment) received 800-mL MilliQ water to induce the same change in salinity than for the other treatments. All the microcosms were closed with a cellulose stopper to allow passive aeration and incubated in the dark at $18^{\circ} \mathrm{C}$, under continuous magnetic agitation during 6 to 7 days.

\section{Chemical and spectroscopic analyses}

Nitrate+nitrite $\left(\mathrm{NO}_{3}{ }^{-}+\mathrm{NO}_{2}\right)$ and phosphate $\left(\mathrm{PO}_{4}{ }^{3-}\right)$ were analyzed by colorimetry using a nutrient autoanalyzer (SEAL Analytical AA3HR). Ammonium $\left(\mathrm{NH}_{4}{ }^{+}\right)$was analyzed by fluorometry using a Jasco FP-2020 fluorometer (Holmes 1999).

Samples for DOC were filtered through 2 precombusted $\left(450^{\circ} \mathrm{C}, 6 \mathrm{~h}\right) 25-\mathrm{mm} \mathrm{GF} / \mathrm{F}$ filters, transferred into precombusted glass tubes, poisoned with $85 \% \mathrm{H}_{3} \mathrm{PO}_{4}$ (final $\mathrm{pH}=2$ ), closed with Teflon lined screw caps and were stored in the dark at room temperature until analysis. DOC was analyzed using the high temperature catalytic oxidation (HTCO) technique (Cauwet 1994) using a Shimadzu TOC-V analyzer. Before starting analyses and between sets of samples, deep seawater reference samples (provided by D. Hansell; Univ. Miami) were run daily (43.5 $\mu \mathrm{M} \mathrm{C}, \mathrm{CV}=2-3 \%, \mathrm{n}=4)$ to check the accuracy of the DOC analysis and its stability over time. Samples for dissolved organic nitrogen (DON) and phosphorus (DOP) were filtered through 2 pre-combusted 25-mm GF/F filters (Whatman). Samples were collected directly in Teflon bottles and stored frozen $\left(-20^{\circ} \mathrm{C}\right)$. DON and DOP were simultaneously determined by the wet oxidation procedure (Pujo-Pay and Raimbault 1994). DON $\left( \pm 0.1 \mu \mathrm{mol} \mathrm{L}^{-1}\right)$ and DOP $\left( \pm 0.02 \mu \mathrm{mol} \mathrm{L}^{-1}\right)$ concentrations were determined by sample oxidation $\left(30 \mathrm{~min}, 120^{\circ} \mathrm{C}\right)$ corrected for $\mathrm{NH}_{4}{ }^{+}, \mathrm{NO}_{3}{ }^{-}+\mathrm{NO}_{2}$ and $\mathrm{PO}_{4}{ }^{3-}$ concentrations, respectively.

Chromophoric dissolved organic matter (CDOM) and fluorescent dissolved organic matter (FDOM) were determined on samples filtered through 2 precombusted $\left(450^{\circ} \mathrm{C}, 6 \mathrm{~h}\right) 25-\mathrm{mm}$ GF/F filters (Whatman). CDOM spectra absorption was determined with a Hitachi U-310 spectrophotometer using a 10-cm cuvette. Absorbance was measured against Milli-Q water as blank. Absorption coefficients a $\lambda\left(\mathrm{m}^{-1}\right)$ were calculated as a $\lambda=2.303 \mathrm{D} / \mathrm{L}$ where $\mathrm{D}$ is the absorbance at the $\lambda$ wavelength and $L$ is the path length of the absorbance cell in meters. Absorption coefficients were normalized to DOC concentration, expressed here in units of $\mathrm{L}$ $\mathrm{mol}^{-1} \mathrm{~cm}^{-1}$. FDOM was assessed on a Perkin Elmer LS55 spectrofluometer using a 1-cm quartz cuvette. Fluorescence intensity was calibrated using the Raman scatter peak of Milli-Q water (Lawaetz and Stedmon 2009). The Ex/Em wavelengths used for single measurements were those established by Coble (1996), thus: Ex/Em $250 \mathrm{~nm} / 435 \mathrm{~nm}$ (peak-A) as an 
indicator of a group of humic-like substances with different origins Ex/Em $320 \mathrm{~nm} / 410 \mathrm{~nm}$ (peak-M) as indicator of marine humic-like substances, Ex/Em 340 nm/440 nm (peak-C) as an indicator of terrestrial humic-like substances, and Ex/Em $280 \mathrm{~nm} / 350 \mathrm{~nm}$ (peak-T) as indicator of protein-like substances. Fluorescence measurements were expressed in Raman Units (R.U.) by normalization to the integral water Raman scattering band of ultrapure MilliQ water freshly generated, according to Lawaetz and Stedmon (2009). Fluorescence values were normalized to DOC concentration, expressed here in units R.U. $\mu \mathrm{mol}^{-1}$.

\section{Bacterial abundance and production analyses, DNA extraction and sequencing}

The term bacteria used for abundance and production includes both bacteria and archaea (i.e., all the heterotrophic prokaryotes). Bacterial abundance (BA) was determined by flow cytometry. Samples $(3 \mathrm{~mL})$ were preserved with $0.2-\mu \mathrm{m}$-filtered formalin ( $2 \%$ final concentration) and stored at $-80^{\circ} \mathrm{C}$. The samples were stained with SYBR Green I (final concentration $0.025 \%(\mathrm{v} / \mathrm{v})$ of the commercial solution; Molecular Probes Inc., OR) for at least $15 \mathrm{~min}$ at $20^{\circ} \mathrm{C}$ in the dark and analyzed on a flow cytometer (FACScan, Becton Dickinson, San Jose, CA). Bacterial production (BP) was measured by ${ }^{3} \mathrm{H}$-thymidine incorporation applying the centrifugation method (Smith and Azam 1992). Samples (1 mL in triplicate) were incubated in the dark at $18^{\circ} \mathrm{C}$ for $1 \mathrm{~h}$ with $20 \mathrm{nmol} \mathrm{L}{ }^{-1}\left[{ }^{3} \mathrm{H}\right]$-thymidine (specific activity $83.2 \mathrm{Ci} \mathrm{mmol} \mathrm{L}{ }^{-1}$, Perkin Elmer). To calculate the bacterial growth efficiency (BGE) we first converted the thymidine incorporation rates into carbon production using the conversion factors of $2.10^{8}$ cells produced per mole of thymidine incorporated and a cell carbon content of 12.4 fg C (Ducklow and Carlson 1992 ; Fukuda et al. 1998). Then, BGE was calculated from the following equation BGE $=$ BP integrated / DOC consumption.

For bacterial diversity, samples $(500 \mathrm{~mL})$ were filtered sequentially onto $3 \mu \mathrm{m}$ and $0.22 \mu \mathrm{m}$ pore size polycarbonate filters (Nuclepore). The $0.22 \mu \mathrm{m}$ filters were stored at $-20^{\circ} \mathrm{C}$ until analysis. For analysis, frozen filters were cut with sterilized scissors into small strips and vortexed briefly in $840 \mu \mathrm{L}$ of lysis buffer $\left(50 \mathrm{mmol} \mathrm{L}^{-1}\right.$ Tris hydrochloride $\mathrm{pH} \mathrm{8.3,40} \mathrm{mmol}$ $\mathrm{L}^{-1}$ EDTA and $0.75 \mathrm{~mol} \mathrm{~L}^{-1}$ sucrose). Cell lysis was accomplished by an initial incubation for $45 \mathrm{~min}$ at $37^{\circ} \mathrm{C}$ after adding $50 \mu \mathrm{L}$ of freshly prepared lysozyme solution $\left(20 \mathrm{mg} \mathrm{mL}^{-1}\right)$, and a second incubation at $55^{\circ} \mathrm{C}$ for $1 \mathrm{~h}$ after adding $100 \mu \mathrm{L}$ of $10 \%$ sodium dodecyl sulfate and 10 $\mu \mathrm{L}$ of proteinase $\mathrm{K}\left(20 \mathrm{mg} \mathrm{mL}^{-1}\right)$.

Bacterial tag-encoded FLX amplicon pyrosequencing (bTEFAP) was performed using the universal bacterial primers guidelines targeting the V1 to V3 hypervariable regions of the bacterial 16S rRNA gene: 27Fmod (5'-AGRGTTTGATCMTGGCTCAG-3') and 519r (5'- 
GWATTACCGCGGCKGCTG-3) as described previously (Dowd et al. 2008). Tag-encoded FLX amplicons were sequenced using the Roche 454 FLX instrument with Titanium reagents following manufacturer's guidelines (www.mrdnalab.com, Shallowater, TX, USA).

Sequences were processed and analyzed using the Mothur software version 1.33 following the 454 standard operation procedure (Schloss et al. 2009) with default settings, excluding sequences <200 bp. Sequences were denoised using the Mothur implementation of PyroNoise and chimeras were removed using Chimera Slayer (Haas et al. 2011). The resulting clean sequences were clustered into operational taxonomic units (OTUs) at a 97\% sequence identity level using the UCLUST algorithm (Edgar 2010) and a representative sequence from each OTU was classified using the Ribosomal Database Project (RDP) classifier (Wang et al. 2007) using the SILVA 119 training set. Taxonomic identification of the sequence reads (tags) followed the approach by Sogin et al. (2006) and Huse et al. (2010). To enable betadiversity comparisons between samples, samples were rarefied to the same sequencing depth as the sample with the fewest sequences $(2,462$ sequences per sample for the Rhone experiment and 1,206 for the phytoplankton experiment) (Ghiglione and Murray 2012). All further analyses were performed on the OTU table using Mothur.

\section{Statistical analyses and estimation of the microbial diversity}

Statistical analysis of treatment effects on chemical and biological parameters were performed using a one-way analysis of variance (ANOVA) and post-hoc Tukey tests with repeated measures (i.e. microcosms). Statistical analyses were performed using XLSTAT 2014.2 software (Addinsoft) and employed an alpha level to 0.05 .

Bacterial community structures were compared using ordination of Bray-Curtis similarities and used to build dendrograms by the unweighted-pair group method with arithmetic averages (UPGMA). A similarity profile test (SIMPROF, PRIMER 6) was performed to determine if there was any statistically significant clustering in the samples which were $a$ priori unstructured. The significance of the branch (SIMPROF, p <0.05) was used as a prerequisite for defining bacterial clusters. Similarity percentage analysis (SIMPER, Clarke and Gorley 2006) was performed to identify which individual OTUs contributed most to the dissimilarity between grouped samples over-time. The Chao 1 estimator of species richness, the Smith Wilson evenness index and the inverse Shannon diversity index were calculated in MOTHUR (Schloss et al. 2009). 


\section{Results}

\section{Photochemical transformations of DOM}

The DOM solution obtained from the Chaetoceros sp. culture contained $817 \mu$ mol. $\mathrm{L}^{-1}, 112$ $\mu \mathrm{mol} . \mathrm{L}^{-1}$ and $13 \mu \mathrm{mol} . \mathrm{L}^{-1}$ DOC, DON and DOP, respectively, whereas the DOM solution from the Rhone River contained $137 \mu \mathrm{mol} . \mathrm{L}^{-1}, 7 \mu \mathrm{mol} . \mathrm{L}^{-1}$ and $0.6 \mu \mathrm{mol} . \mathrm{L}^{-1} \mathrm{DOC}$, DON and DOP, respectively. No significant changes in these concentrations, nor those of inorganic nutrients $\left(\mathrm{NO}_{3}{ }^{-}+\mathrm{NO}_{2}, \mathrm{NH}_{4}{ }^{+}, \mathrm{PO}_{4}{ }^{3-}\right)$, were observed after light exposure (data not shown) suggesting an absence of photoremineralization for both DOM sources. In contrast, changes in DOM absorbance and fluorescence properties were observed for both DOM sources after light exposure (Fig. 1 and 2). Absorbance at $350 \mathrm{~nm}$ decreased by $71 \%$ and $47 \%$ for the phytoplankton DOM and riverine DOM, respectively (Fig. 1). When fluorescence peaks are normalized to DOC concentration, higher values for peaks A, C and M (humic substances) were measured for riverine DOM, whereas phytoplankton-derived DOM showed higher value for peak T (protein-like substances) (Fig. 2). After light exposure, the different fluorescence peaks decreased for both DOM but to different extents. For phytoplankton DOM, the major decrease was observed for Peak T (-85\%), whereas the other peaks decreased by $54-59 \%$. Similarly, but to a lower extent, DOM from the Rhone River showed a higher decrease for Peak T (-43\%) than for other fluorescence peaks (between -29\% and -35\%).

\section{Biodegradation of DOM}

For the biodegradation experiment with phytoplankton DOM, the DOC concentrations at T0 were $80.0 \pm 0.6 \mu \mathrm{mol} . \mathrm{L}^{-1}$ in the control microcosms, and $104 \pm 2.7 \mu \mathrm{mol} . \mathrm{L}^{-1}$ in the enriched microcosms (Fig. 3a). After 6 days, DOC decreased by $6.4 \mu \mathrm{mol} . \mathrm{L}^{-1}$ in the control microcosms and by $22-25 \mu \mathrm{mol} . \mathrm{L}^{-1}$ in the enriched microscosms regardless of the DOM pretreatment. By comparing the enriched and the control microcosms, we estimate that $70 \%$ of the DOC from the phytoplankton was degraded over 6 days. The addition of DOM from phytoplankton (irradiated or not) in the microcosms resulted in an enrichment in inorganic nutrients by $7.5 \mu \mathrm{mol} . \mathrm{L}^{-1}, 0.08 \mu \mathrm{mol} . \mathrm{L}^{-1}$ and $0.65 \mu \mathrm{mol} . \mathrm{L}^{-1}$ for $\left(\mathrm{NO}_{3}{ }^{-}+\mathrm{NO}_{2}\right), \mathrm{NH}_{4}{ }^{+}$and $\mathrm{PO}_{4}{ }^{3-}$, respectively (data not shown).

For the biodegradation experiment with riverine DOM, the DOC concentrations at T0 were $76.1 \pm 2.5 \mu \mathrm{mol} . \mathrm{L}^{-1}$ in the control microcosms and $98.4 \pm 1.3 \mu \mathrm{mol} . \mathrm{L}^{-1}$ in the enriched microcosms (Fig. 3b). After 7 days, DOC decreased by $8 \mu \mathrm{mol} . \mathrm{L}^{-1}$ in the control microcosms 
and by $10-12 \mu \mathrm{mol} . \mathrm{L}^{-1}$ in the enriched microcosms regardless of the DOM pretreatment. By comparing the enriched and the control microcosms, we estimate that $13 \%$ of the DOC from the Rhone River was degraded over 7 days. The addition of riverine DOM (irradiated or not) in the microcosms resulted to an enrichment in inorganic nutrients by $14.5 \mu \mathrm{M}, 0.36 \mu \mathrm{mol} . \mathrm{L}^{-1}$ and $0.15 \mu \mathrm{mol} . \mathrm{L}^{-1}$ for $\left(\mathrm{NO}_{3}{ }^{-}+\mathrm{NO}_{2}\right), \mathrm{NH}_{4}{ }^{+}$and $\mathrm{PO}_{4}{ }^{3-}$, respectively (data not shown).

\section{Changes in bacterial abundance and production during the biodegradation experiment}

The addition of phytoplankton-derived DOM or riverine DOM led to the stimulation of bacterial growth during the two first days of the experiments compared to the controls without DOM addition (Fig. 4a,b). The bacterial growth was higher in the case of phytoplanktonderived DOM compared to the riverine DOM experiment. Moreover a significant difference in bacterial abundance was observed at days 1, 2 and 3 in the phytoplankton-derived DOM experiment between non-irradiated and irradiated treatments (ANOVA, p<0.05), with lower values observed for the latter treatment. In contrast, bacterial abundance in the riverine DOM experiment was not significantly different for the different light treatments. After 2 days, a decrease of bacterial abundance was observed in both experiments suggesting a tight control of bacteria by heterotrophic nanoflagellates or viruses that were kept unchanged by the microcosms preparation. Bacterial abundance in the amended microcosms decreased to similar values measured in the unamended microcosms after 6 days in the phytoplanktonderived DOM experiment and after 3 days in the riverine DOM experiment.

As for bacterial abundance, addition of phytoplankton-derived DOM led to a higher stimulation of bacterial production compared to the addition of riverine DOM (Fig. 4c,d), with a significant difference $(\mathrm{p}<0.05)$ between the two light treatments at days 1 and 2 (lower values with DOM irradiated). The bacterial growth efficiency calculated for the first stage of the biodegradation (0-3 days) was slightly higher, but not significantly different ( $p>0.05)$, for the phytoplankton-derived DOM (i.e., 39\%) compared to the riverine DOM (i.e., 36\%). When both types of DOM were previously exposed to solar radiation, the BGE values were not significantly modified $(\mathrm{p}>0.05)$.

Changes in the bacterial diversity induced by the addition of DOM non-irradiated or irradiated

The initial bacterial community (T0) was analyzed from a single sample (phytoplankton DOM experiment) or duplicate samples (Rhone River DOM experiment) by performing pyrosequencing of partial bacterial $16 \mathrm{~S}$ rRNA genes. The same analysis was performed for 
each treatment in duplicate microcosms after 3 days for the phytoplankton DOM experiment and after 7 days for the Rhone River DOM experiment. We decided to sample earlier the bacterial diversity in the phytoplankton DOM experiment to identify which bacterial species were the most affected by the slower bacterial growth observed after the DOM irradiation. After trimming and quality control, a total of 11,473 partial 16S rRNA sequences with an average of 7,801 (1,206-17,589) per sample and 83,924 sequences with an average of 7,836 sequences per sample $(2,462-16,100)$ were obtained for the phytoplankton DOM experiment and for the Rhone River DOM experiment, respectively. The sequences were then clustered into OTUs at $>97 \%$ similarity and normalized to the respective sample with the fewest sequences (i.e 1,206 for the phytoplankton DOM experiment and 2,462 for the Rhone River DOM experiment). In both experiments the number of OTUs and the richness and evenness indexes did not change significantly between the different light treatments ( $p>0.05$; Table 1$)$. In contrast, a lower Inverse Simpson index was measured in both experiments in the treatment where irradiated DOM was added ( $\mathrm{p}<0.05$; Table 1) compared to non-irradiated DOM. We cannot compare the numbers of OTUs or the diversity indexes between the two experiments, because we have not rarefied to the same number of sequences.

After 3 days of incubation, hierarchical clustering based on Bray-Curtis similarities revealed a pattern in which the bacterial community structure was clearly influenced by the enrichment of DOM from the phytoplankton (Fig. 5a). Whereas the similarity between the initial community and the control microcosms remained high (70\%), the addition of phytoplankton DOM led to a low similarity of $25 \%$ with the initial community. Moreover, a significant difference (SIMPROF $\mathrm{p}<0.05$ ) was observed between the two light treatments on DOM, showing that the photodegradation of phytoplankton-derived DOM had an impact on the bacterial community structure.

For the Rhone experiment, a profound modification of the bacterial community was observed after 7 days of incubation between the initial community and the unamended microcosms ( $20 \%$ similarity, SIMPROF $\mathrm{p}<0.05$ ) for which the salinity has been reduced by $20 \%$ to mimic the same change in salinity than in amended microcosms (Fig. 5b). The bacterial diversity was also significantly modified by the addition of DOM from the Rhone River compared to the control microcosms (55\% similarity, SIMPROF $\mathrm{p}<0.05)$, however, no significant difference was observed between the microcosms enriched with irradiated and non-irradiated DOM (SIMPROF, $\mathrm{p}>0.05)$. 
The bacterial community composition was investigated by comparing the relative abundance of the major phyla and the proteobacteria subclasses (Fig. 6). The main effects induced by the addition of phytoplankton-derived DOM compared to the control were a reduction of Alphaproteobacteria and an increase of Gammaproteobacteria (Fig. 6a). We can also notice the appearance of a small percentage of Betaproteobacteria. As mentioned above, the DOM irradiation led to a modification in the bacterial composition, with more Alphaproteobacteria (48\%) and less Gammaproteobacteria (26\%) compared to the addition of non-irradiated DOM (30\% and 40\%, respectively). The main effects induced by the addition of riverine DOM compared to the control were the opposite to those observed with the phytoplankton DOM, i.e., an increase in Alphaproteobacteria $52-60 \% \%$ in the enriched microcosms vs $42 \%$ for the controls) and a decrease in Gammaproteobacteria (19\% in the enriched microcosms vs $42 \%$ in the controls) (Fig. 6b). A small increase in Betaproteobacteria and Planctomycetes was also observed when riverine DOM was added.

To identify the OTUs that contributed the most to the dissimilarities observed in the phytoplankton DOM experiment between irradiated and non irradiated DOM, we performed a similarity percentage analysis (SIMPER). The list of the 44 OTUs explaining $80 \%$ of the dissimilarity between the two treatments and the relative contribution of these OTUs in each treatment, is presented in Table 2 . These OTUs were equally distributed between those stimulated and those inhibited by the light treatment on DOM. The dissimilarity observed between the two treatments was mainly explained by few OTUs. Two OTUs belonging to the genus Roseovarius and Nereida (Alphaproteobacteria, Rhodobacteraceae) were more abundant when the DOM from the phytoplankton was previously irradiated (25.6\% and 6.9\%, respectively) compared to the non-irradiated DOM (11.5\% and 3.0\%, respectively). On the contrary, an OTU belonging to the genus Vibrio (Gammaproteobacteria, Vibrionaceae) and the OTU NS2b (Bacteroidetes, Flavobacteriacea) were more abundant in the treatment with the non-irradiated DOM (17.3\% and $17.7 \%$, respectively) than with the irradiated DOM (12.1\% and $9.4 \%$, respectively). These four OTUs explained $44.4 \%$ of the dissimilarity between the two treatments. 


\section{Discussion}

\section{Photochemical transformations of DOM and bacterial metabolic activity coupling}

The irradiation used in this study was not sufficient to induce photomineralization (loss of DOC, DON or DOP) of diatom-derived DOM and riverine DOM. However, we observed clear signals of photobleaching on CDOM and FDOM for both DOM sources after the simulated sunlight exposure. FDOM analysis confirmed as expected that phytoplankton DOM is characterized by a higher proportion of protein-like substances (peak-T), whereas riverine DOM contained more humic-like substances (peaks -M, -C, -A). Protein-like substances were more photobleached than humic-like substances for both DOM origins. Indeed, the light sensitivity of protein-like substances compared to the humic-like substances is quite variable in the literature and could be due to structural arrangement by which tryptophan or tyrosine was bound to larger proteins (Zang et al., 2013 and references herein). Based on the absorbance and fluorescence measurements, diatom-derived DOM appeared to be more susceptible to photobleaching than riverine DOM. The two DOM sources were also characterized by a clear difference in lability: despite the same quantity of DOC added in both biodegradation experiments $\left(\sim 23 \mu \mathrm{mol} . \mathrm{L}^{-1}\right)$, the stimulation of the bacterial growth and the quantity of DOC consumed were largely higher in the phytoplankton DOM experiment compared to the riverine DOM experiment. The addition of phytoplankton and riverine DOM were also associated with an enrichment in inorganic nutrients that was slightly higher in the case of the diatom-derived DOM (see Results). The changes in bacterial growth observed after the DOM addition are the net effects of all the organic materials and inorganic nutrients added and we cannot conclude on the respective role of each element. Because bacteria present in surface waters of the Mediterranean Sea are often limited by phosphorus (Van Wambeke et al., 2002), the enrichment of this element with the addition of DOM can partly explain the bacterial stimulation. However, because preliminary DOM irradiation did not increase inorganic nutrients, we are insured that changes observed on bacterial growth between the two light treatments were more certainly due to changes in DOM lability.

In the case of the phytoplankton DOM, previous light treatment had induced a slight lowering in bacterial growth and production during the three first days, while the quantity of DOC degraded remained the same over the experiment. This suggests that DOM products were used with less efficiency by bacteria (a larger part was respired and not used for biomass production). However, when the bacterial growth efficiency (BGE) was calculated using the 
integrated value of bacterial carbon production, no significant differences were observed between the two light treatments. This result can be affected by the uncertainties of the calculation considering the small changes in DOC concentrations measured at small time scale that generate differences between the replicate microcosms. The lowering of the BGE after DOM phototransformations has been observed in different studies and was attributed to the production of oxidized molecules (e.g., organic acids) that are expected to be utilized at a lower BGE compared with less oxygenated, more reduced substrates for energetic reasons (Abboudi et al. 2008). Recently, Amado et al. (2015) observed a delayed bacterial biomass production when a mixture of amino acids (one of the bioavailable molecules produced by phytoplankton) was previously exposed to simulated solar radiation. The authors interpret this result as the need for bacteria to up regulate their biosynthetic pathways for amino acids that are damaged by photochemically produced reactive oxygen species (ROS). Inhibition of bacterial growth can also be induced by the toxic effect of ROS on bacteria (Amado et al. 2015).

Contrary to phytoplankton-derived DOM, we did not measure a significant effect of irradiation on bacterial growth/production for the riverine DOM. Actually, riverine DOM is composed of a complex mixture of organic molecules with different degrees of lability. Consequently, contrasting photochemical reactions may occur during irradiation resulting in the absence of net effects on metabolic activity. For instance, the DOM fluorescence analysis revealed the presence of both humic substances that are presumed to produce more labile DOM after irradiation and protein like substances that are presumed to produce less labile DOM after irradiation. Moreover, our experimental design differed from the most common approach used to determine the changes in bacterial metabolism or composition in response to DOM photo-oxidation. These experiments are generally performed by irradiating sterilefiltered natural water samples and then inoculating bacteria to follow the changes in these diluted cultures. These regrowth experiments can favour opportunistic bacterial species with high growth rates which can lead to a biased view of bacterial composition and changes in metabolic activities (Fuchs et al. 2010). To avoid this, we decided here to dilute the irradiated DOM in a bacterial community by maintaining a "natural" bacterial abundance at the start of the experiment. The changes observed in such experiments are certainly smaller than those observed in regrowth experiments but probably more realistic.

Changes in bacterial composition in response to photochemical transformations of DOM 
For the unirradiated treatment, the addition of phytoplankton-derived DOM induced a higher proportion of Gammaproteobacteria whereas riverine DOM favored Bacteroidetes and Alphaproteobacteria. Even if the comparison of both experiments is complicated because the initial bacterial community was different (one month separates both experiments) and the time selected to analyze the diversity was also different (3 and 7 days), our observations are coherent with other ones. Indeed, Gammaproteobacteria and more specifically the Alteromonadales and Vibrionales orders are frequently associated to the degradation of fresh labile organic matter underlying their opportunistic life style, characterized by rapid growth and their ability to quickly take up a range of substrates when favorable conditions occur (Landa et al. 2013 ; Blanchet et al. 2015). This could explain the presence of higher relative abundance of those bacterial groups after the amendment of phytoplankton-derived DOM. On the contrary, Bacteroidetes has been associated to the degradation of high molecular weight compounds (Fernandez-Gomez et al. 2012) and Alphaproteobacteria to the degradation of humic substances (Rocker et al. 2012).

In the case of phytoplankton-derived DOM, the light treatment induced additional changes in bacterial community composition. Such effect of photochemical transformation of DOM on bacterial diversity has been previously reported. Judd et al. (2007) observed that sunlightexposed DOM from lakes and streams had a positive effect on bacterial production and caused shifts in bacterial community composition (based on denaturating gradient gel electrophoresis of bacterial-specific 16S rDNA). Pérez and Sommaruga (2007) also reported that photodegradation of DOM from different origins (lakes, algae, soil) influenced the activity and the composition of the bacterial communities (based on fluorescent in situ hybridization), with an increase in the relative contribution of Actinobacteria when DOM was pre-exposed to the solar radiation. Abboudi et al. (2008) used DNA and RNA fingerprints and showed that photochemical transformation of DOM from coastal lagoons and coastal water induced a shift in bacterial community structure. Piccini et al. (2009) observed a rapid modification of bacterial community composition from a coastal lagoon in response to the photodegradation of CDOM in favour of Alpha and Betaproteobacteria. More recently, Paul et al. (2012) demonstrated that bacterial communities of non-irradiated and UV-irradiated DOM from different origins were different and that UV selected for specific members of Alphaproteobacteria, Betaproteobacteria and Bacteriodetes. The fact that we did not observe changes in the bacterial diversity after photodegradation of riverine DOM can be due to the surperimposed effect of change in salinity. Indeed, after seven days, the bacterial composition 
in the control treatment was greatly modified as a consequence of the decrease in salinity, but possibly also by the dilution of inorganic nutrients and the effect of confinement.

The changes in bacterial composition after DOM photodegradation can be initiated by the selection of bacterial species more adapted to the use of phototransformed DOM and/or less sensitive to the short-lived reactive oxygen species generated during photochemical reaction (Glaeser et al. 2010). These different observations underline the importance to of determining with further precision which bacterial groups are stimulated or inhibited by the DOM photodegradation according to its origin.

All the previous diversity studies were performed at a low taxonomic level, using fingerprinting methods or CARD-FISH and they underline the necessity of determining with further precision which bacterial groups are stimulated or inhibited by the DOM photodegradation according to its origin. In our study we used a 16S rRNA pyrosequencing which allowed us to assess changes in bacterial community structure at different taxonomic levels down to the OTU level. We observed that Alphaproteobacteria responded positively to the phototransformation of phytoplankton DOM whereas Gammaproteobacteria was negatively affected compared to the dark control. The identification of OTUs by pyrosequencing enabled us to show a contrasted response within each bacterial phylum and within the Proteobacteria subclasses. For instance, among the Bacteroidetes, 5 OTUs were inhibited and 9 OTUs were stimulated. For the Alphaproteobacteria, 8 OTUs were inhibited and 7 OTUs were stimulated. Finally, for the Gammaproteobacteria, 9 OTUs were inhibited and 4 OTUs were stimulated. These results show clearly increased phylogenetic resolution is crucial to describe the changes in bacterial diversity in response to photo-oxidized DOM.

The two main OTUs positively affected by irradiated DOM contributing to $25 \%$ of the light treatment dissimilarity, belonged to the genera Roseovarius and Nereida belonging to the family Rhodobacteraceae (Alphaproteobacteria) (Table 2). These bacteria could be more adapted to using photo-oxidized DOM or less sensitive to the reactive species of oxygen produced during the DOM irradiation and added to the microcosms (Glaeser et al. 2010). Interestingly, Roseovarius was detected in the bacterial community attached to lightened phytodetritus (Petit et al. 2015). This environment is characterized by a high concentration of toxic oxygen species (mainly singlet oxygen) produced by phytoplankton during its senescence. The resistance of Roseovarius to oxidative stress could be explained by its content in carotenoids acting as a singlet oxygen quencher. The Rhodobacteraceae family, and more specifically the genus Nereida, was dominant in a bacterial community after 
exposure to the natural sunlight with UV radiation during 8 days (Manrique et al. 2012). In this case, the changes in bacterial community can result not only from the response of bacteria to photo-oxidized DOM, but also to a selection of a bacterial community more resistant to UV radiation or more able to use the DOM produced by the phytoplankton species selected by UV radiation.

\section{Conclusion and perspectives}

This study confirmed that photo-oxidation of different DOMs have contrasting effects on bacterial metabolism depending on the origins of the DOM. A negative effect on bacterial growth and production has been observed for the phytoplankton-derived DOM, whereas no effect was observed for the river DOM, may be due to a higher compositional diversity, including both recalcitrant and labile compounds. Our results also point out the importance of using an approach with sufficient resolution for determining changes in bacterial composition induced by DOM phototransformation due to the contrasting response of bacteria inside a same class, or even a family. Based on our results and those of previous studies, some members of Alphaproteobacteria seem particularly adapted for using DOM photoproducts. The use of transcriptomic and proteomic analysis will be useful in the future to describe which genes/proteins are expressed in response to DOM phototransformation (Moran et al. 2016). The identification of these genes/proteins first experimentally and then in the natural environments will greatly improve our comprehension of the coupling between the bacterial community and the photochemical reactions. This question is of particular interest in the Mediterranean Sea where increased impact of solar radiation on both DOM and microbial communities is expected due to stronger vertical stratification induced by the global warming (Mermex group 2011). Mediterranean Sea is also characterized by a large gradient of productivity from eutrophic to ultra oligotrophic waters with contrasting quantity and quality of DOM. The role of the biological degradation and photoinduced degradation, and the interaction of both, on residence time, cycling and fate of these different DOM qualities remains an open question. Further studies are needed to correctly model these interactions. 


\section{Acknowledgements}

We thank Christine Sotin (CEFREM, UMR5110, Perpignan, France) for water sampling in the Rhône. We thank Philippe Catala and Jocelyne Caparros for flow cytometry and DOC analyses, respectively. This study was conducted as a part of the WP4MERMEX/MISTRALS funded by INSU-CNRS (PHOTOMED research project). The authors thank Nyree West for linguistic corrections and constructive comments that improved the manuscript. We are grateful to the BIO2MAR platform (http://bio2mar.obs-banyuls.fr) for providing technical support and access to instrumentation. The $\mathrm{PhD}$ scholarship for $\mathrm{MB}$ was provided by University Pierre et Marie Curie (ED129) and the Ministry of Research and Technology.

\section{References}

Abboudi, M., Jeffrey, W.H., Ghiglione, J-F., Pujo-Pay, M., Oriol, L., Sempéré, R., Charrière, B., Joux, F., 2008. Effects of photochemical transformations of dissolved organic matter on bacterial metabolism and diversity in three contrasting coastal sites in the northwestern Mediterranean Sea during summer. Microbial Ecology 55, 344-357.

Amado, A.M., Cotner, J.B., Cory, R.M., Edhlund, B.L., McNeill, K., 2015. Disentangling the interactions between photochemical and bacterial degradation of dissolved organic matter: amino acids play a central role. Microbial Ecology 69, 554-566.

Benner, R., Biddanda, B. 1998. Photochemical transformations of surface and deep marine dissolved organic matter: effects on bacterial growth. Limnology and Oceanography 43, 1373-1378.

Bertilsson S, Tranvik LJ (2000) Photochemical transformation of dissolved organic matter in lakes. Limnology and Oceanography 45, 753-762.

Blanchet M., Pringaut O., Bouvy M. Catala P., Oriol L., Caparros J., Ortega E., Intertaglia L., West N., Agis M., Got P., Joux F., 2015. Changes in bacterial community metabolism and composition during the degradation of dissolved organic matter from the jellyfish Aurelia aurita in a Mediterranean coastal lagoon. Environmental Science and Pollution Research 22, 13638-13653.

Buchan, A., LeCleir, G.R., Gulvik, C.A., Gonzáles, J.M., 2014. Master recyclers: features and functions of bacteria associated with phytoplankton blooms. Nature Reviews Microbiology 12, 686698.

Cauwet, G., 1994. HTCO method for dissolved organic carbon analysis in seawater: influence of catalyst on blank estimation. Marine Chemistry 47, 55-64.

Clarke, K., Gorley, R., 2006. Primer v6: User Manual/Tutorial In. Ltd, P.-E. (ed). Plymouth, UK.

Comte, J., and P.A. Del Giorgio., 2011. Composition influences the pathway but not the outcome of the metabolic response of bacterioplankton to resource shifts. PLoS ONE 6, e25266.

Cotner, J.B., Biddanda, B.A., 2002. Small players, large role: microbial influence on biogeochemical processes in pelagic aquatic ecosystems. Ecosystems 5, 105-121. 
Diaz, F., Naudin, J.-J., Courtier, C., Rimmelin, P., Oriol, L., 2008. Biogeochemical and ecological functioning of the low-salinity water lenses in the region of the Rhone River freshwater influence, NW Mediterranean Sea. Continental Shelf Research 28, 1511-1526.

Dowd, S.E., Callaway, T.R., Wolcott, R.D., Sun, Y., McKeehan, T., Hagevoort, R.G., Edrington, T.S., 2008. Evaluation of the bacterial diversity in the feces of cattle using 16S rDNA bacterial tag-encoded FLX amplicon pyrosequencing (bTEFAP). BMC Microbiology 8, 125.

Ducklow HW, Carlson CA (1992) Oceanic bacterial production. In: Marshall KC (ed) Advances in microbial ecology. Springer, US, pp 113-181

Edgar, R.C., 2010. Search and clustering orders of magnitude faster than BLAST. Bioinformatics 26, 2460-2461.

Fernández-Gómez, B., Richter, M., Schüler, M., Pinhassi, J., Acinas, S.G., González, J.M., PedrósAlió, C., 2012. Ecology of marine Bacteroidetes: a comparative genomics approach. ISME Journal 7, $1026-1037$.

Fuchs BM, Zubkov MV, Sahm K, Burkill PH, Amann R., 2000. Changes in community composition during dilution cultures of marine bacterioplankton as assessed by flow cytometric and molecular biological techniques. Environmental Microbiology 2, 191-201.

Fukuda, R., Ogawa, H., Nagata, T., and Koike, I., 1998. Direct determination of carbon and nitrogen contents of natural bacterial assemblages in marine environments. Applied Environmental Microbiology 64, 352-3358.

Ghiglione, J-F., Murray, A.E., 2012. Pronounced summer to winter differences and higher wintertime richness in coastal Antarctic marine bacterioplankton. Environmental Microbiology 14, 617-629.

Glaeser, S.P., Grossart, H-P., Glaeser, J., 2010. Singlet oxygen, a neglected but important environmental factor: short-term and long-term effects on bacterioplankton composition in a humic lake. Environmental Microbiology 12, 3124-3136.

Haas BJ, Gevers D, et al., 2011. Chimeric 16S rRNA sequence formation and detection in Sanger and 454-pyrosequenced PCR amplicons. Genome Research 21, 494-504.

Holmes, R.M., Aminot, A., Kérouel, R., Hooker, B.A., Petersen, B.J., 1999. A simple and precise method for measuring ammonium in marine and freshwater ecosystems. Canadian Journal Fish Aquatic Science 56, 1801-1808.

Huse, S.M., Welch, D.M., Morrison, H.G., Sogin, M.L., 2010. Ironing out the wrinkles in the rare biosphere through improved OTU clustering. Environmental Microbiology 12, 1889-1898.

Joux, F,, Jeffrey W.H., Abboudi, M., Pujo-Pay, M., Oriol, L., Neveux, J., Naudin, J-J., 2009. Ultraviolet radiation in the Rhône lenses of low salinity and marine waters of the northwestern Mediterranean Sea: attenuation and effects on bacterial production and net community production. Photochemistry Photobiology 85, 783-793.

Judd, K.E., Crump, B.C., Kling, G.W., 2007. Bacterial response in activity and community composition to photo-oxidation of dissolved organic matter from soil and surface waters. Aquatic Sciences 69, 96-107.

Kirchman, D.L., Dittel, A.I., Findlay, S.E.G., Fischer, D., 2004. Changes in bacterial activity and community structure in response to dissolved organic matter in the Hudson River, New-York. Aquatic Microbial Ecology 35, 243-257.

Landa, M., Cottrel, M.T., Kirchman, D.L., Blain, S., Obernosterer, I., 2013. Changes in bacterial diversity in response to dissolved organic matter supply in a continuous culture experiment. Aquatic Microbial Ecology 69, 157-168.

Lawaetz, A.J., Stedmon, C.A., 2009. Fluorescence intensity calibration using the Raman scatter peak of water. Applied Spectroscopy 63, 936-940. 
Lønborg, C., Martínez-García, S., Teira, E., Álvarez-Salgado, X.A., 2013. Effects of the photochemical transformation of dissolved organic matter on bacterial physiology and diversity in a coastal system. Estuarine Coastal and Shelf Science 129, 11-18.

Lønborg, C., Nieto-Cid, M., Hernando-Morales, V., Martínez-Ruiz, M., Teira, E., Álvarez-Salgado, X.A., 2016. Photochemical alteration of dissolved organic matter and the subsequent effects on bacterial carbon cycling and diversity. FEMS Microbiology Ecology 92, fiw048

Manrique, J.M., Cavo, A.Y., Halac, S.R., Villafañe, Jone, L.R., Helbing W.E., 2012. Effects of UV radiation on the taxonomic composition of natural bacterioplankton communities from Bahía Engaño (Patagonia, Argentina) Journal of Photochemistry and Photobiology B: Biology 117, 171-178.

Mermex Group, 2011. Marine ecosystems' responses to climatic and anthropogenic forcings in the Mediterranean. Progress Oceanography 91, 97-166.

Mopper, K., Kieber, D., Stubbins, A., 2015. Marine photochemistry of organic matter: processes and impacts. In: Biogeochemistry of marine dissolved organic matter. (Eds., Hansell DA, Carslon CA). 2nd edition, Academic Press, San Diego. 389-450.

Moran, M.A. et al., 2016. Deciphering ocean carbon in a changing world. Proc Natl Acad Sci USA $113,3143-3151$.

Paul, A., Dziallas, C., Zwirnmann, E., Gjessing, E.T., Grossart, H-P., 2012. UV irradiation of natural organic matter (NOM): impact on organic carbon and bacteria. Aquatic Sciences 74, 443-454.

Pérez, M.T., Sommaruga, R., 2007. Interactive effects of solar radiation and dissolved organic matter on bacterial activity and community structure. Environmental Microbiology 9, 2200-2210.

Petit, M., Bonin, P., Amiraux, R., Michotey, V., Guasco, S., Armitano, J., Jourlin-Castelli, C., Vaultier, F., Méjean, V., Rontani, J-F., 2015. Dynamic of bacterial communities attached to lightened phytodetritus. Environmental Sciences and Pollution Research 22, 13681-13692.

Piccini, C., Conde, D., Pernthaler, J., Sommaruga, R., 2009. Alterations of chromophoric dissolved organic matter by solar UV radiation causes rapid changes in bacterial community composition. Photochemistry Photobiology Sciences 8, 1321-1328.

Pujo-Pay, M., Raimbault, P., 1994. Improvement of the wet oxidation procedure for simultaneous determination of particulate organic nitrogen and phosphorus collected on filters. Marine Ecology Progress Series 105, 203-207.

Repeta, D.J., 2015. Chemical characterization and cycling of dissolved organic matter. In: Biogeochemistry of marine dissolved organic matter. (Eds., Hansell DA, Carslon CA). 2nd edition, Academic Press, San Diego. 21-63.

Rocker D, Brinkhoff T, Grüner N, Dogs M, Simon M., 2012. Composition of humic acid-degrading estuarine and marine bacterial communities. FEMS Microbiology Ecology 80, 45-63.

Schloss, P.D., Westcott, S.L., Ryabin, T., Hall, J.R., Hartmann, M., Hollister, E.B., Lesniewski, R.A., Oakley, B.B., Parks, D.H., Robinson, C.J., Sahl, J.W, Stres, B., Thallinger, G.G., Van Horn, D.J., Weber, C.F., 2009. Introducing mothur: open-source, platform-independent, community-supported software for describing and comparing microbial communities. Applied Environmental Microbiology $75,7537-7541$.

Sempéré R., Para J., Tedetti M., Charrière B., Mallet M., 2015. Variability of solar radiation and CDOM in surface coastal waters of the northwestern Mediterranean Sea. Photochemistry and Photobiology 91, 851-861.

Smith, D.C., Azam, F., 1992. A simple, economical method for measuring bacterial protein synthesis rates in seawater using ${ }^{3} \mathrm{H}$-leucine. Marine Microbial Food Webs 6, 107-114.

Sogin ML, Morrison HG, Huber JA, Welch DM, Huse SM, Neal PR, Arrieta JM, Herndl GJ (2006) Microbial diversity in the deep sea and the underexplored "rare biosphere". Proc Natl Acad Sci USA 103, 12115-12120. 
Tranvik, L.J., and Kokalj, S., 1998. Decreased biodegradability of algal DOC due to interactive effects of UV radiation and humic matter. Aquatic Microbial Ecology 14, 301-307.

Van Wambeke, F., Christaki, U., Giannakourou, A., Moutin, T., Souvemerzoglou, K., 2002. Longitudinal and vertical trends of bacterial limitation by phosphorus and carbon in the Mediterranean Sea. Microbial Ecology, 43, 119-133.

Wang, Q., Garrity, G.M., Tiedje, J.M., Cole, J.R., 2007. Naïve Bayesian classifier for rapid assignment of rRNA sequences into the new bacterial taxonomy. Applied Environmental Microbiology 73, 5261-5267.

Wawrik, B., Paul J.H., 2004. Phytoplankton community structure and productivity along the axis of the Mississippi River plume in oligotrophic Gulf of Mexico waters. Aquatic Microbial Ecology 35, 185-196.

Zhang, Y., Liu, X., Osburn, C. L., Wang, M., Qin, B., Zhou, Y., 2013. Photobleaching response of different sources of chromophoric dissolved organic matter exposed to natural solar radiation using absorption and excitation-emission matrix spectra. PLoS ONE 8, e77515

Zingler, L., Gobet, A., Pommier, T., 2012. Two decades of describing the unseen majority of aquatic microbial diversity. Molecular Ecology 21, 1878-1896. 
Table 1. Alpha diversity for the phytoplankton DOM (T0 and 3 days incubation) and the Rhone River DOM experiments (T0 and 7 days incubation) presented as Number of OTUs, the inverse Simpson diversity index, species richness (Chao 1 index), and species evenness (Smith Wilson index) calculated on randomly picked OTUs. Each value represents the mean of two replicates ( \pm standard deviation) with the exception of the T0 for the phytoplankton DOM experiment where only one sample was analyzed.

Table 2. List of the OTUs explaining $80 \%$ of the dissimilarity observed after 3 days between the microcosms enriched with non-irradiated DOM and irradiated DOM from phytoplankton. The relative abundance of OTUs is expressed as the percentage of total sequences obtained for each treatment (two replicates). The contribution of each OTU to the dissimilarity between treatments was analyzed with SIMPER.

\section{Figures Legend}

Fig. 1. Changes in absorption properties of phytoplankton-derived DOM (a) and riverine DOM (b) before (T0) and after $24 \mathrm{~h}$ irradiation (Light) or dark treatment (Dark).

Fig. 2. Changes in fluorescence properties of phytoplankton-derived DOM (a) and riverine DOM (b) before (T0) and after 24h irradiation (Light) or dark treatment (Dark). Each value represents the mean of three replicates samples ( \pm standard deviation) divided by the dissolved organic carbon (DOC) concentration measured in these samples. Peak-A is an indicator of a group of humic substances with different origins, peak-M is an indicator of marine humic-like substances, peak-C is an indicator of terrestrial humic-like substances, and peak- $\mathrm{T}$ is as indicator of protein-like substances. The percentages of loss after light treatment relative to dark treatment are indicated for each peak.

Fig. 3. Dissolved organic carbon (DOC) concentrations followed during the biodegradation experiments with the phytoplankton-derived DOM (a) and the riverine DOM (b). Each value represents the mean of three replicates microcosms ( \pm standard deviation). Lower case letters indicate groups of non-significantly different values for each experiment (ANOVA $\mathrm{p}>0.05$ ).

Fig. 4. Changes in bacterial abundance (a,b) and production (c,d) during the biodegradation of the phytoplankton-derived DOM $(\mathrm{a}, \mathrm{c})$ and the riverine DOM $(\mathrm{b}, \mathrm{d})$. Each value represents the 
mean of three replicates microcosms ( \pm standard deviation). Arrows indicate the date when bacterial diversity was analyzed.

Fig. 5. Similarity dendrograms based on the OTU tables from the $16 \mathrm{~S}$ rDNA 454-tag sequences for the initial community (T0) and in the control microcosms and those enriched with non-irradiated DOM or irradiated DOM from the Chaetoceros culture (a) and from the Rhone River (b) after 3 days and 7 days, respectively. Clustering is on the basis of a distance matrix computed using the Bray-Curtis index of similarity. The dendrogram was inferred with the unweighted pair-group average algorithm (UPGMA). Bacterial communities in the samples connected with red branch lines are not significantly different (SIMPROF test, $\mathrm{p}$ $>0.05)$.

Fig. 6. Relative abundance of the main bacteria phyla and proteobacteria subclasses expressed as the percentage of total sequences for the initial community (T0), in the control microcosms and those enriched with non-irradiated DOM or irradiated DOM from the Chaetoceros culture (a) and from the Rhone River (b) after 3 days and 7 days, respectively. 
Table 1

\begin{tabular}{|c|c|c|c|c|c|}
\hline \multicolumn{2}{|l|}{ Experiment } & \multirow{2}{*}{\begin{tabular}{|l} 
OTUs \\
209
\end{tabular}} & \multirow{2}{*}{$\begin{array}{c}\begin{array}{c}\text { Diversity } \\
\text { (Inv. Simpson) }\end{array} \\
22.4\end{array}$} & \multirow{2}{*}{$\begin{array}{c}\begin{array}{c}\text { Richness } \\
\text { (Chao) }\end{array} \\
530\end{array}$} & \multirow{2}{*}{$\begin{array}{c}\begin{array}{c}\text { Evenness } \\
\text { (Smith Wilson) }\end{array} \\
0.288\end{array}$} \\
\hline Phytoplankton DOM & Initial community & & & & \\
\hline & Control & $210(10)$ & $17.5(3.1)$ & $520(127)$ & $0.272(0.020)$ \\
\hline \multirow[t]{2}{*}{ T3 } & DOM non- & $193(10)$ & $173(13)$ & $458(176)$ & 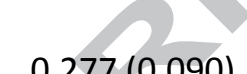 \\
\hline & DOM irradiated & $203(2)$ & $\begin{array}{l}17.3(1.3) \\
12.1(0.2)\end{array}$ & $525(40)$ & $0.239(0.021)$ \\
\hline \multirow[t]{4}{*}{ Rhône River DOM } & Initial community & $247(56)$ & $15.5(2.3)$ & $632(366)$ & $0.354(0.033)$ \\
\hline & Control & $216(18)$ & $11.1(0.7)$ & $561(226)$ & $0.372(0.021)$ \\
\hline & $\begin{array}{l}\text { DOM non- } \\
\text { irradiated }\end{array}$ & $250(38)$ & $13.2(2.9)$ & $622(148)$ & $0.353(0.011)$ \\
\hline & DOM irradiated & $236(7)$ & $7.4(0.4)$ & $670(15)$ & $0.322(0.007)$ \\
\hline
\end{tabular}


Table 2

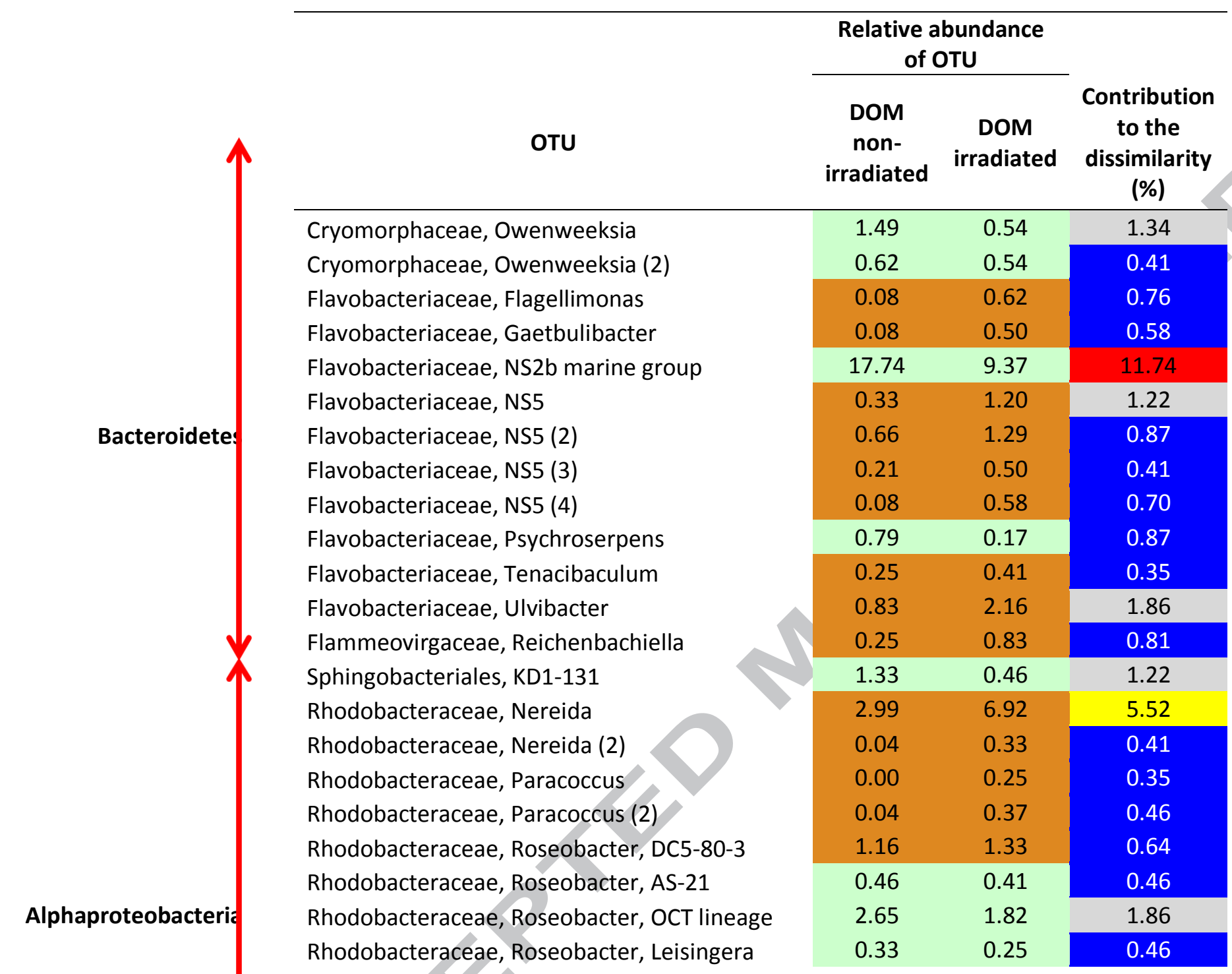




\section{Betaproteobacteria}

\section{Gammaproteobacteria}

Verrucomicrobia
Rhodobacteraceae, Roseobacter, Jannaschia Rhodobacteraceae, Roseovarius

Rickettsiales, SAR116

Rickettsiales, SAR116 (2)

Rickettsiales, SAR116 (3)

SAR11

SAR11

Methylophilaceae, OM43

Alteromonadaceae, Glaciecola

Alteromonadaceae, Glaciecola (2)

Alteromonadaceae, Glaciecola (3)

Colwelliaceaea, Colwellia

Pseudoalteromonadaceae, Pseudoalteromonas

Pseudoalteromonadaceae, Pseudoalteromonas

(2)

KI89A_clade

Litoricolaceae, Litoricola

Oceanospirillaceae, Marinomonas

Oceanospirillaceae, Marinomonas (2)

SAR86

Vibrionaceae, Vibrio

Vibrionaceae, Vibrio (2)

Puniceicoccaceae, marine group

$\mathrm{n}=44$

\begin{tabular}{|c|c|c|}
\hline 0.25 & 1.37 & 1.57 \\
\hline 11.48 & 25.66 & 19.87 \\
\hline 0.58 & 0.17 & 0.58 \\
0.46 & 0.25 & 0.41 \\
\hline 0.58 & 0.17 & 0.58 \\
\hline
\end{tabular}

$\begin{array}{lll}3.86 & 2.45 & 1.98\end{array}$

\begin{tabular}{ll|l}
1.82 & 1.41 & 0.81
\end{tabular}

$\begin{array}{lll}0.70 & 1.12 & 0.58\end{array}$

$\begin{array}{lll}0.81 & 4.10 & 1.34\end{array}$

$\begin{array}{lll}0.08 & 0.37 & 0.41\end{array}$

$\begin{array}{lll}0.46 & 0.29\end{array}$

$\begin{array}{lll}0.37 & 0.12 & 0.35\end{array}$

$\begin{array}{lll}5.39 & 3.11 & 3.20\end{array}$

$\begin{array}{lll}0.37 & 0.17 & 0.35\end{array}$

$\begin{array}{lll}1.04 & 0.83 & 0.87\end{array}$

$\begin{array}{lll}0.41 & 0.25 & 0.58\end{array}$

$\begin{array}{lll}2.78 & 2.80 & 0.87\end{array}$

$\begin{array}{lll}2.40 & 0.37 & 2.85\end{array}$

$\begin{array}{lll}0.00 & 0.33 & 0.46\end{array}$

$\begin{array}{lll}0.00 & 17.29 & 12.06\end{array}$

\begin{tabular}{ll|l}
0.75 & 0.17 & 0.81
\end{tabular}

$\begin{array}{lll}0.04 & 0.37 & 0.46\end{array}$

$\begin{array}{lll}\text { SUM }= & \text { SUM }= & \text { SUM }=80 \% \\ 87.3 \% & 88.8 \% & \end{array}$

lower after DOM irradiation

higher after DOM irradiation 
Highlights - PROOCE_2016_165

Our results demonstrate that the effects of solar radiation on DOM greatly differ according to the initial composition of DOM and that changes in bacterial composition, when occurred, showed diverse responses inside a same class of bacteria, underlying the necessity to use a sufficiently resolutive approach to describe them. 